\title{
Observations on the Flora of Japan.
}

(Continued from p. 82.)

\author{
By \\ T. M a k i n o. \\ Lecturer of Botany in the Science College, \\ Imperial University of Tokyo.
}

Prunus serrulata Lindl, in Trans. Hort. Soc. VII. (1830), p. 238 ; Walp. Repert. II. p. 8.

var, albida Makino. (Fig. IX.)

subvar. a. hortualis Makino.

Prunus pseudo-Cerasus var. $\gamma$. serrulata subvar. b. Sieboldi forma albida Makino in Bot. Mag., Tokyo, XXII. (1908), p. 102.

Prunus serrulata $\alpha$. serrulata forma albida Makino, 1. c. XXIII. (1909), p. 74.

Tree; branchlets terete, glabrous, rufescent-castaneous, thinly dispersed with small punctiform lenticels; young one glabrous. Young leaves in flowering time tufted, protected with perulæ at the base, long-petiolate, obovato-elliptical or elliptical, caudatoacuminate, duplicately and simply setaceo-serrulate, shining, viridescent and thinly shaded with purple above, glabrous; veins parallel and prominent beneath; stipule angustato-linear, acuminate, longer than the petiole, simple, loosely glanduloso-ciliated, viridescent. Perulæ (of bud) imbricated, deciduous after flower or in flower; the exterior ones badio-brick-coloured, thinly crustaceous, rounded at the apex, the lower ones smallest and semiorbicular, the upper ones gradually larger and rounded to oval, densely puberulent under the apex internally, ciliated on the upper margin in the inner ones; the interior ones larger, erect-patent or spreading, herbaceous, obovato-spathulate, glanduloso-ciliated, pubescent internally, viridescent but albescent at the base, usually tinged with reddish-purple above externally, $8-18 \mathrm{~mm}$. long, $6-10 \mathrm{~mm}$. broad, the inner ones often 


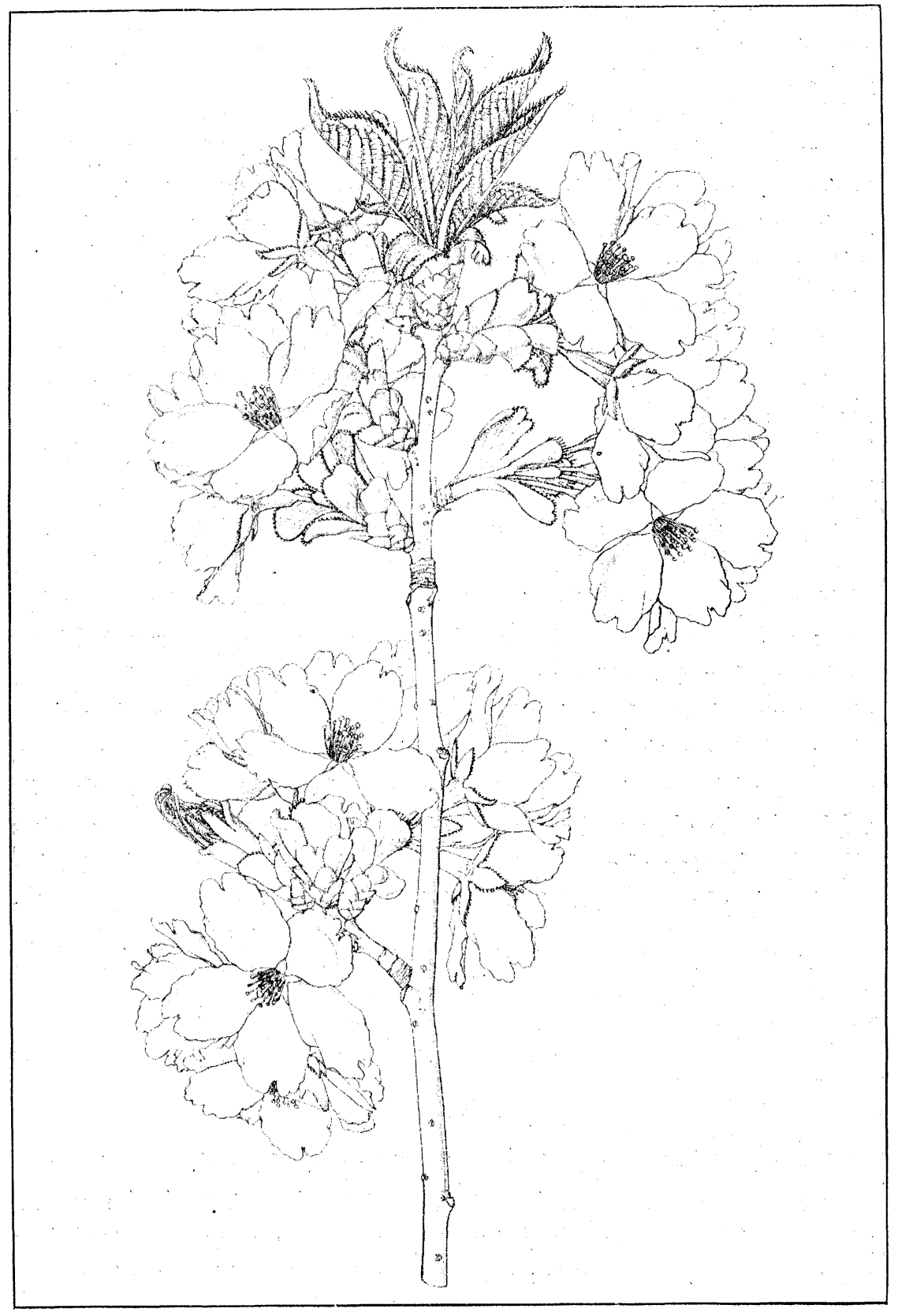

FIG. IX. nat. size. 
shallowly or deeply 3-fid at the apex; those of leaf-bud similar to those of the flower-bud, but the inner ones usually larger and often 3-parted or deeply 3-fid. Inflorescence protected with perulæ at the base, umbellately about 3-4-flowered; common peduncle very short, glabrous, viridescent, about 3-4 mm. long; pedicels fasciculate, erect or erect-patent, terete, rather stout, glabrous or pubescent, viridescent but often shaded with purple above, about 13-22 $\mathrm{mm}$. long; bracts herbaceous, viridescent and often thinly shaded with purple, sessile, 4-5, unequal in size and larger and broader in the outer ones, cuneato-obovate, rounded or truncate at the apex, glandulosodenticulato-ciliated, glabrous externally, very thinly pubescent internally, anastomotic-veined above, deciduous, attaining $14 \mathrm{~mm}$. long, $10 \mathrm{~mm}$. wide. Flowers coetaneous or subprecocious, about $3 \frac{1}{2} \mathrm{~cm}$. across, compact, white but lately purpurascent in the bottom of the corolla, inodorous. Calyx glabrous, viridescent and usually tinged with purpurascent hue, deciduous ; tube straight, oblong-tubular, somewhat enlarged above, 6-8 $\mathrm{mm}$. long, $4-4 \frac{1}{2} \mathrm{~mm}$. across in the upper broader part, glabrous, obscurely veined longitudinally, acutely continued to the pedicel at the base, smooth but rugulose above on the surface, viridescent and nectariferous below internally; lobes 5 , with obtuse sinuses between lobes, nearly equal to or very slightly shorter than the tube, ovato-lanceolate, acuminate, incumbently glanduloso-ciliated with several to subnumerous setæ on each margin, 3-nerved, 7-8 $\mathrm{mm}$. long, $3 \frac{1}{2}-4 \mathrm{~mm}$. broad. Petals 5, sub-erect-patently patent, oval-elliptical, sessile and obtuse at the base, emarginate with rounded or obtuso-rounded and entire or suberoso-crenate lobes, and often with a small produced tip in the bottom of the open or subclose sinus, loosely subcrispate towards the margin and uneven on face, glabrous, $17-19 \mathrm{~mm}$. long, $12-14 \mathrm{~mm}$. broad. Stamens numerous, short, erect, inserted on the throat and the upper portion of the calyx-tube internally, unequal in length, attaining about $6 \frac{1}{2} \mathrm{~mm}$. in length; filament subulato-filiform, glabrous, white but lately purpurascent at the base; anther small, rounded, yellow, emarginate at the apex, bifid at the base, introrse, 
with oblong anther-cells. Style 1 , erect, nearly equal to the stamens in height, about 11-12 mm. long, slenderly terete, glabrous, viridescent, with a fine ventral line on one side; stigma small, dilated, elliptical-orbicular, concave in centre, viridescent, about $1 \frac{1}{2} \mathrm{~mm}$. across; ovary 1 , sessile, oval-ovoid or ovoid-ellipsoid, erect, glabrous, green, with a sutural line on one side, $1 \frac{1}{2}-2 \mathrm{~mm}$. long, $1 \frac{1}{2} \mathrm{~mm}$. across, 2-ovuled.

Nom. Jap. Shiro-satozakura (nov.).

Hab. Prov. Musashi : Tokyo, cultivated (T. Makino!).

This is distinguished by the broad perulæ, broad bracts, very short common peduncle, short pedicels, compact and white simple flower, and not fully patent corolla. It is uncommon in gardens.

subvar. b. speciosa (Koidz.) Makino. (Fig. X.)

Prunus jamasakura $\beta$. speciosa Koidz. in Bot. Mag., Tokyo, XXV. (1911), p. 186.

Tree, attaining about $14 \mathrm{~m}$. or more in height; trunk erect, attaining about $27 \mathrm{~cm}$. or more in diameter; main branches erect-patent, cinereo-castaneous, transverse-verrucous with old large cross lenticels; branches cinereo-castaneous, terete, thinly verrucous with old lenticels; branchlets terete, glabrous, rufescent-castaneous, thinly dispersed with punctiform lenticels; young branchlet viridescent or purpurascent, terete, smooth, often slightly flexuous, glabrous. Leaves alternate, petiolate, obovato-elliptical, oval-elliptical, or obovato-oval, abruptly caudato-acuminate at the apex, rounded or subtruncato-rounded at the base, and with 1-3 minute discoidal sessile glands on margin near the petiole, duplicately and simply setaceo-serrate, chartaceo-membranaceous, glabrous, green above, paler beneath, $4-14 \mathrm{~cm}$. long, 2-7 $\frac{1}{2} \mathrm{~cm}$. broad; midrib impressed above and prominent beneath as well as the veins; veins $8-11$ on each side, erect-patent, more or less arcuate above; main-veinlets transversed between the veins; minute-veinlets finely anastomosing; petiole long, slender, glabrous, viridescent and often tinged with purple, with 1-3 minute discoidal sessile glands in the apical portion, $2-3 \frac{1}{4} \mathrm{~cm}$. long; young leaves (in the flowering time) scarcely viscid, shining, green, but usually very thinly 


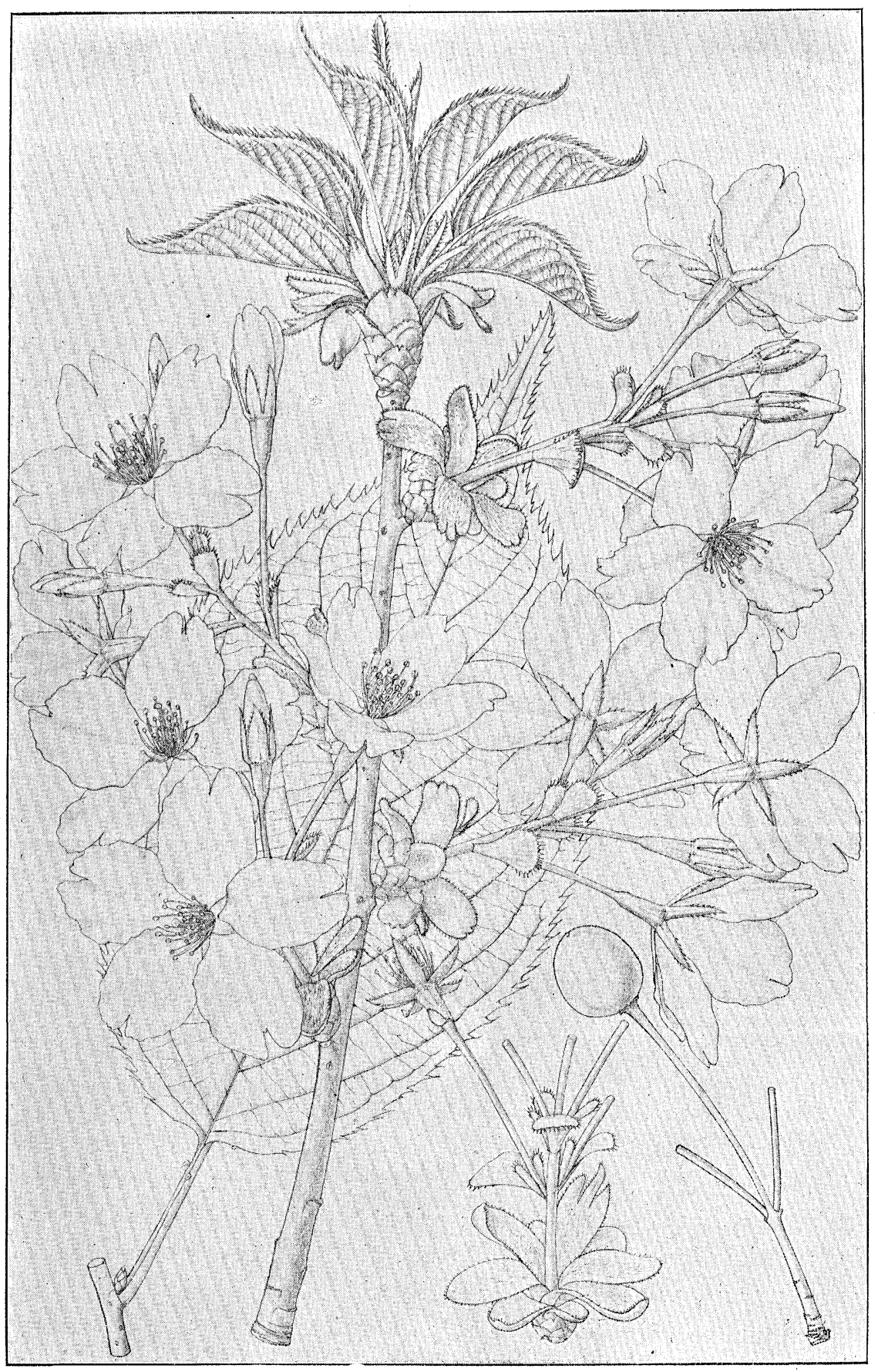

FIG. X. nat. size. 
or deeply shaded with purpurascent tint, tufted and protected by the perulæ at the base of the leaf-tuft, quitely glabrous, with a slender glabrous petiole and very angustate long stipules; blade at first conduplicate, obovato-elliptical, abruptly caudato-acuminate, setaceo-serrate, shining; midrib and veins prominent beneath; petiole with 2-4 minute discoidal purple glands in the apical portion, canaliculated in front, viridescent and often purpurascent, attaining about $3 \mathrm{~cm}$. long; stipules mainly few-laciniate into augustato-linear divisions, ciliatofimbriate with spreading and unequal glandular (gland purpurascent) teeth, viridescent or thinly shaded with purpurascent hue, deciduous, attaining about $3 \frac{1}{4} \mathrm{~cm}$. long. Perulæ (of flower-bud) deciduous when flower or lately after flowering, imbricated ; the exterior ones small and squamiform, gradually larger above, crustaceous, smooth, badio-brown, rounded at the apex, glabrous but densely puberulent with rufous hairs under the apex internally, the lower ones smallest and semiorbiculate, the middle ones broadly ovato-orbicular, the upper ones ovalorbicular, ciliated; the interior ones much larger and herbaceous, radiately spreading or recurvospreading, viridescent, pubescent internally, glabrous and often shaded with purpurascent or reddishpurpurascent hue dorsally or on both surfaces, ciliatodenticulated with glandular erect-patent or patent teeth, the lower ones oval-elliptical to obovato-elliptical, rounded at the apex, the upper largest, obovato-spathulate

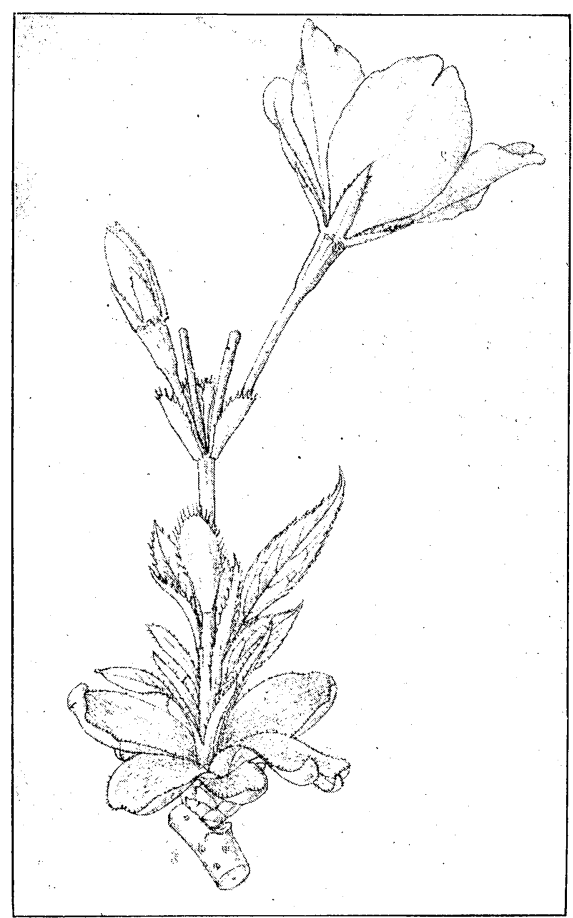

FIG. XI. nat. size. 
or oblong-spathulate or cuneate, usually 3 -fid at the apex, the largest one attaining about $24 \mathrm{~mm}$. long, $12 \mathrm{~mm}$. wide, sometimes situated in the lower portion and often developed into small leaves with petiole and stipules (Fig. XI.) ; those of leafbud similar to those of the flower-bud, but the interior ones often larger, broader and attaining about $30 \mathrm{~mm}$. long, $18 \mathrm{~mm}$. wide in the largest one, deciduous. Inflorescence 3-9-flowered, protected by perulæ at the base; common peduncle short or elongated, straight, subcompresso-terete, glabrous and viridescent as are the pedicels, $\frac{1}{4}-5 \mathrm{~cm}$. long; rachis attaining about $3 \frac{1}{3} \mathrm{~cm}$. long; pedicels $3-9$, corymboso-umbellately or subcorymboso-racemosely or umbellately disposed, erect-patent, straight, rather stout or slender, terete, smooth, often thinly shaded with purpurascent hue above, $1 \frac{\sqrt{3}}{3}-4 \frac{1}{2} \mathrm{~cm}$. long; bracts about 4-10, sessile, obovate, obovato-spathulate, or lato-obovate, but oblong-lanceolate or obovato-cuneate with an acute or acutish or obtuse apex in the inner ones; obtuse or rounded-obtuse or subtruncato-rounded or truncate at the apex, cuneate or subcuneate at the base, ciliato-denticulate with glandular teeth on margin, erect-patent or subspreading, unequal in size, thin, herbaceous, glabrous but usually very thinly pubescent on the upper surface, viridescent but often thinly shaded with purpurascent tint dorsally, with anastomotic veinlets above, $7-15 \mathrm{~mm}$. long, 3-12 $\mathrm{mm}$. broad; the outer one sometimes sub-trifid or rarely sub-laciniate; sometimes in well developed ones provided with bracteoles within the bract at the very base of pedicels, the bracteoles opposite or solitary, smaller than bracts, spathulato-oblanceolate or linear, others as the bract. Flowers coetaneous with young leaves, often rather large, about $3-4 \frac{1}{2} \mathrm{~cm}$. across, white or with a very thin shade of rose, but at first dilute-rosy towards the upper margin of petals, and lately purpurascent in the bottom of the corolla, odoriferous; alabastra oblong-conical, protected by calyx-lobes which are close to it. Calyx glabrous, herbaceous, light green but shaded with purpurascent tint, about $1 \frac{3}{4}-2 \frac{1}{5} \mathrm{~cm}$. across ; tube straight, tubular, somewhat enlarged above, shorter than lobes, more or less nervato-striate longitudinally, shining, rugulose on surface to- 
wards the top, green and nectariferous except the apical portion internally, about $5-7 \mathrm{~mm}$. long, $3 \frac{1}{2}-4 \mathrm{~mm}$. across in the apical broader part; lobes 5 , with obtuse sinuses between lobes, patent, sometimes then reflexed, ovato-lanceolate, oblong-lanceolate or lanceolate, shortly or abruptly or attenuately acuminate, subincumbent-ciliato-serrulate with several to many teeth on each side, thin, with 3 main nerves, shining dorsally, 7-11 mm. long, $2 \frac{1}{2}-4 \mathrm{~mm}$. wide. Petals 5 , patent or erect-patently patent, elliptical, oval-elliptical, or oblong-elliptical, entire and slightly loosely crispate towards margin, shortly broad-cuneate with an about right or acutich angle and sessile at the base, emarginate with rounded lobes and sometimes a minute projecting tip in the bottom of the subclose or open sinus at the apex, membranaceous, glabrous, deciduous, 18-23 mm. long, 11-16 mm. broad. Stamens rather short, numerous, erect, inserted on the throat and the inner side of the apical portion of the calyx-tube, glabrous, the outer longest ones about $9 \mathrm{~mm}$. long; filament subulato-filiform, white then rosy-purpurascent below; anther minute, rounded, bifid at the base, introrse, yellow, $1 \mathrm{~mm}$. long and across, with oblong anther-cells and yellow pollen. Style 1 , erect, equal to or lower than or slightly exserted upon the stamens in height, narrowly terete, with a fine sutural line on one side throughout, glabrous, viridescent, about $10-12 \mathrm{~mm}$. long; stigma small, dilated, depressed-orbicular, concave in centre, subnotched on one side, green; ovary sessile, ovoidelliptical, with a sutural line on the ventral side, glabrous,

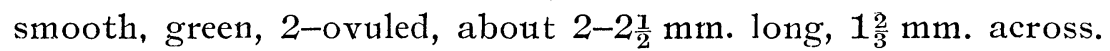
Drupe globular, but in young stage oval-ellipsoid and shortly mucronate at the apex, about $1-1 \frac{1}{4} \mathrm{~cm}$. across, dark-purple, succulent, smooth, 1-4 to a common peduncle; pedicel strict, glabrous, erect-patent, dilatato-enlarged at the apex, $2 \frac{1}{2}-3 \frac{1}{2} \mathrm{~cm}$. long; putamen oval, acutish at the apex, rounded at the base, slightly compressed, smooth on face, $8 \mathrm{~mm}$. long; embryo ovalellipsoid, mucronate, somewhat compressed; common peduncle straight, glabrous, $1-3 \frac{1}{4} \mathrm{~cm}$. long, very rarely with one or two small petiolate leaves below.

Nom. Jap. Ôshima-zakura. 
Hab. Prov. Musashi : Yokohama, cultivated from Isl. Ôshima, one of the Seven Islands of the province of Idzu ( $T$. Makino! 1911, fruit, 1912, flower).

This is commonly planted in Isl. Ôshima, and its wood is used for fuel in the island. It differs from subvar. a. hortualis Makino by having the longer common peduncle, longer pedicels, larger flower, and more patent and often purple-shaded petals, etc.

Trachelospermum jasminoides Lem. Jard. Fleur. I. tab. 61 ; Van Houtte, F1. des Serres, VI. p. 263, tab. 615.

Rhynchospermum jasminoides Lindl.; Bot Mag. tab. 4737 ; Franch. et Sav. Enum. P1. Jap. I. p. 315.

Nerium divaricatum Thunb. Fl. Jap. p. 100, non Linn.

Trachelospermum divaricatum Kanitz, Anthoph. Jap. (1878), p. 14; K. Sch. in Engl. et Prantl, Nat. Pfl.-Fam. IV. 2, p. 167, fig. $58 \mathrm{I}-\mathrm{L}$.

Malouetia asiatica Sieb. et Zucc. in Abh. Akad. Muench. IV. 3, p. 163.

Parechites Thunbergii A. Gray, Bot. Jap. p. 403; Miq. Prol. F1. Jap. p. 63.

Leaves entirely glabrous.

Nom. Jap. Teika-kadzura.

Hab. Japan.

var. pubescens Makino, nov.

Leaves pubescent towards the midrib beneath. Otherwise as in the type.

Nom. Jap. Ke-teikakadzura (nov.).

Hab. Prov. Harima : Akashi (T. Makino!).

Potamogeton teganumensis Makino, nom. nov.

Potamogaton lucens var. teganumensis Makino in Bot. Mag., Tokyo, XIX. (1905), p. 142.

Nom. Jap. Gasha-moku, Chakkara-moku.

Hab. Prov. Shimoosa : Lake Teganuma (K. Yamadsuta!; H. Nakano!; T. Makino!). 